\title{
VEGETATION SUCCESSIONS OVER 30 YEARS OF HIGH COUNTRY GRASSLAND INVASION BY PINUS CONTORTA
}

\author{
N.J. LEDGARD ${ }^{1}$ and T.S.H. PAUL ${ }^{2}$ \\ ${ }^{1}$ Scion, PO Box 29237, Fendalton, Christchurch, New Zealand \\ ${ }^{2}$ Scion, Private Bag 3020, Rotorua, New Zealand \\ Corresponding author: nick.ledgard@scionresearch.com
}

\begin{abstract}
The invasion of a high country grassland site $(850 \mathrm{~m}$ asl) by lodgepole or contorta pine (Pinus contorta, Dougl.) wildings was monitored over 32 years in the Craigieburn Range, Canterbury. The first wildings appeared in 1975 . By 1985 , density had reached $34,550 \mathrm{stems} /$ ha, with a mean height of $1.85 \mathrm{~m}$ and a basal area of $17 \mathrm{~m}^{2} /$ ha. By 2007, stocking had dropped to $11,400 \mathrm{stems} / \mathrm{ha}$, with a mean top height of $14.3 \mathrm{~m}$ and a basal area of $104 \mathrm{~m}^{2} /$ ha. Thirty-eight plant species were present 10 years after wilding invasion started. Twenty-six species (68\%) were indigenous. By 2007, the number of species present had dropped to seven, none of which were indigenous. The introduced tussock hawkweed (Hieracium lepidulum) featured in both assessments. It was concluded that more species are likely to invade as the canopy opens up, but if native species are wanted they may have to be introduced by artificial seeding.

Keywords: Pinus contorta, natural regeneration, wilding tree, invasion, vegetation, successions.
\end{abstract}

\section{INTRODUCTION}

Hundreds of thousands of hectares are affected by the natural regeneration of introduced conifers in New Zealand (Hunter \& Douglas 1988; Ledgard 2004). Lodgepole or contorta pine (Pinus contorta) is commonly recognised as the most vigorous invasive conifer, and although rarely planted today, remains the dominant species in many areas where wildings are a problem (Ledgard 2001). Like a number of pines, contorta is a pioneer species, which can quickly dominate invaded grasslands and open shrublands and forest. However, it is a light-demanding species that will not regenerate under its own canopy unless a major disturbance is involved. There is circumstantial evidence to suggest that more shade-tolerant species, including many native species, will invade under mature contorta stands, especially as they reach a later successional stage and start to 'open up' due to destabilising events such as strong winds and heavy snows. However, there are no long-standing studies to quantify this in New Zealand.

In the Hut Creek catchment of Craigieburn Forest Park in inland central Canterbury, the first contorta pine was planted in 1959 (Ledgard \& Baker 1988), and was recorded as spreading in the mid-1970s. In 1980, a $200 \mathrm{~m}^{2}$ plot was established in grassland immediately alongside a stand of contorta pine planted in 1961, to monitor the invasion of wildings, and their effects on the resident vegetation. Assessments were carried out until 1985 when they ceased due to a shift in direction of research resources. Fortunately, the plot pegs, tree tags and measurement records survived over the next 22 years, so that a complete remeasurement was possible in 2007. This paper describes the vegetation changes that have taken place between 1980 and 2007.

\section{Trial site}

\section{METHODS}

The trial is situated in Hut Creek (NZ Topographic Map 260 K34, E 0550, N 8330), a small tributary of Cave Stream, which flows into Broken River before reaching the 
Waimakariri River. It is on a $22^{\circ}$ slope with a south-westerly aspect at an altitude of $850 \mathrm{~m}$ asl. Being close to the valley floor, it is reasonably sheltered, but can be reached by the prevailing strong north-west winds, which would blow seed directly from the adjacent parent stand into the trial block. The original mountain beech (Nothofagus solandri var. cliffortioides) forest cover was removed by burning in the mid 1800s. Subsequent grazing and burning until the early 1960s resulted in a degraded fescue grassland with large patches of subsoil where the topsoil had been eroded away. The Acidic Allophanic Brown soil (Hewitt 1992) is classified as a member of the Tekoa set (NZ Dept of Scientific and Industrial Research 1968). Temperatures are mild (mean summer $13.9^{\circ} \mathrm{C}$, mean winter $\left.2.0^{\circ} \mathrm{C}\right)$, with adequate rainfall $(1450 \mathrm{~mm})$ spread evenly throughout the year. Ground frosts have been recorded around 150 days annually, and can occur at any time during the growing season (Ledgard \& Baker 1988).

\section{Measurements}

The study block is rectangular, measuring $20 \times 10 \mathrm{~m}$, with the northern boundary running between $4-6 \mathrm{~m}$ from the edge of the parent seed stand. The block is divided into one hundred $2.0 \mathrm{~m} \times 1.0 \mathrm{~m}$ plots, arranged in ten $20 \mathrm{~m}$ rows across the slope. At the first assessment in 1980 (5 years after the first wildings arrived), all contorta pine seedlings were number tagged, measured for height and their age (and hence year of arrival) determined by counting the number of branch whorls. Further assessments of tree numbers, ages, diameters at breast height (diameter) and heights were made annually at the end of all growing seasons until (and including) 1985, with every new seedling being tagged. After 1985, the next measurement was in 2007.

Vegetation transects ( $20 \mathrm{~m}$ long) were laid out across the trial area along plot rows $2,4,6,8$ and 10 . Changes in vegetation were monitored using frequency counts (Allen et al. 1983) inside $15 \mathrm{~cm}$ diameter rings spaced at $40 \mathrm{~cm}$ intervals along the transects. These assessments were carried out in 1980, 1981, 1984, 1985 and 2007.

\section{RESULTS \\ Number, basal area and height of contorta pine trees}

The number of contorta pine stems increased from 500/ha in 1975 to 34,550/ha in 1985 (Fig. 1). At this time, 10 years after the first wilding arrival, the total number of pines on the sites was starting to level out and by 2007, when assessments were resumed, the number had dropped to 11,400 stems/ha.

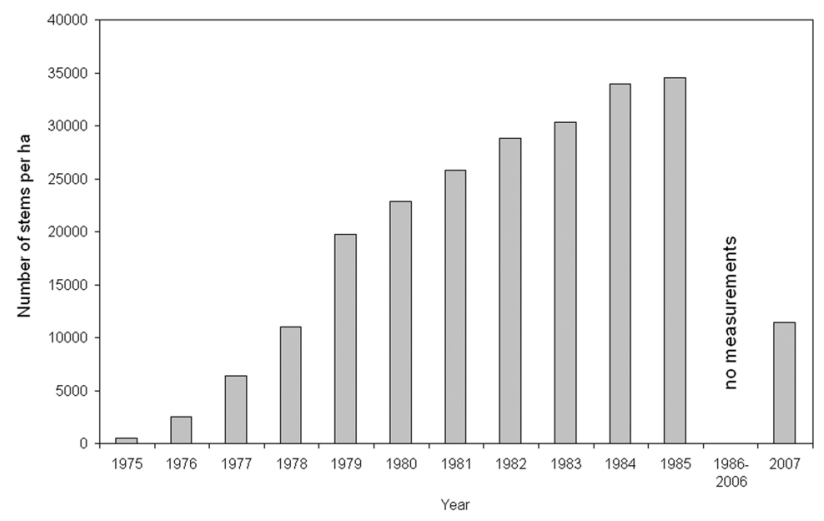

FIGURE 1: Number of contorta pine stems per hectare from 1975 to 2007.

The basal area of live contorta pine trees in 1985 had reached $17.4 \mathrm{~m}^{2} / \mathrm{ha}$, and between 1985 and 2007 it increased to $104.0 \mathrm{~m}^{2} /$ ha at a mean rate of $3.95 \mathrm{~m}^{2} / \mathrm{ha} /$ year (Fig. 2). In the years 1982 to 1985 the mean annual basal area increase was higher, at $4.8 \mathrm{~m}^{2} /$ ha/year. 


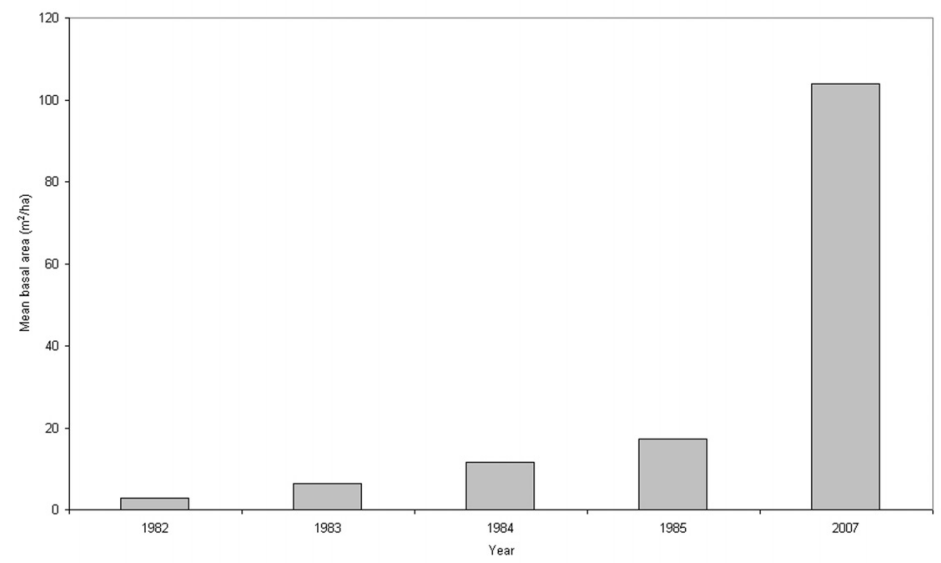

FIGURE 2: Mean basal area of live contorta pine trees from 1982 to 2007.

The mean height of contorta pine trees in 1980 had reached $48 \mathrm{~cm}$. The mean height of the trees increased at an almost constant rate from 1980 to 1985, when the mean height was just under $200 \mathrm{~cm}$ (Fig. 3). Between 1985 and 2007, many trees were damaged and malformed by snow and wind events. In 2007, the mean height of intact (undamaged) trees was $620 \mathrm{~cm}$. Of the intact trees, the mean top height of the 100 largest diameter trees was $1,430 \mathrm{~cm}$.

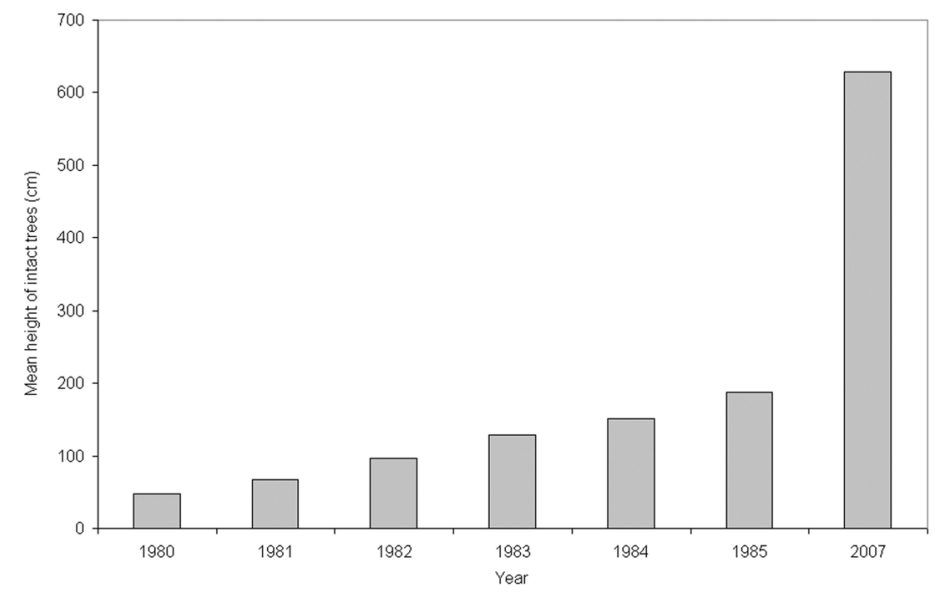

FIGURE 3: Mean height of intact (not damaged) contorta pine trees from 1980 to 2007.

\section{Stem damage}

The percentage of damaged trees was low between 1980 and $1985(<1 \%)$, but as the trees matured, dense stocking led to dead tops (mostly in smaller trees) and thin spindly stems, which were very susceptible to damage by wind and, particularly, snow. In 2007 , $37 \%$ of the trees had dead tops or had bent stems and/or had their tops broken. Most of these were in the smaller diameter classes. 


\section{Vegetation}

Between 1975 and 1985 the numbers of contorta pine seedlings increased rapidly, but the canopy remained sufficiently open to allow a range of native and introduced plant species to persist. Thirty-eight plant species were found in the study plot in 1981 . The most common species are listed in Table 1.

The species composition up until 1985 was characterised by grasses (mostly introduced) and native herb species. However, with the increasing establishment and growth of pines, the less shade-tolerant native species were suppressed and disappeared, so that in 2007 the ground cover contained only five exotic vascular species plus a moss and a lichen (Table 1).

Grasses, like sweet vernal (Anthoxanthum odoratum) and Festuca novae-zealandiae, were abundant in 1980 but decreased quite rapidly up until regular assessments ceased in 1985. On the other hand, the frequency of another grass, browntop (Agrostis capillaris) increased slightly during this period as did the fern Blechnum penna-marina, but overall most species either maintained or decreased their frequency as pine dominance rose. The two hawkweeds (H.lepidulum and H. praealtum) maintained their cover until 1985, and in 2007 were the only species that remained from the original ground cover vegetation, although with much reduced frequency. The only other species present in 2007, besides the two Hieracium species, were two tree species, Douglas-fir (Pseudotsuga menziezii) and rowan (Sorbus aucuparia), and the grass, Yorkshire fog (Holcus lanatus).

\section{Development of the $P$. contorta stand}

\section{DISCUSSION}

The combination of ample seed, together with an existing sparse ground cover on the trial site, led to a rapid increase in contorta seedlings between 1975 and 1985. A study of seedling ages indicates that the peak period of establishment occurred in 1977 and 1978. By 1980, 5 years after invasion began, the establishment of new contorta pine seedlings was already slowing down. It appears that pines that had established earlier had already filled most of the potential seedling sites. By 1985, seedling density had reached 34,550 stems/ha. Although this might appear high, densities of young $P$. contorta seedlings regenerating in the American north-west after fire have been recorded at well over 100,000 stems/ha (Lotan \& Perry 1983). In 2007 at Craigieburn, inter-tree competition had led to a $33 \%$ drop in stocking, down to 11,400 stems/ha, whilst basal area had climbed from under $5 \mathrm{~m}^{2} /$ ha to $104 \mathrm{~m}^{2} / \mathrm{ha}$. As expected, the majority of this basal area (70\%) was held in the larger trees, even though they represented only $17 \%$ of the total number of stems. The 2007 basal area is similar to the basal area recorded $\left(94 \mathrm{~m}^{2} / \mathrm{ha}\right)$ in plots of similar aged contorta pine located in a planted stand $100 \mathrm{~m}$ away from the present trial (A. Nordmeyer, pers. comm.).

A feature of the study area in 2007 was the high number of trees with broken tops and bent stems - many were bent over $90^{\circ}$ from around $2 \mathrm{~m}$ above ground level. Thirty-seven percent of trees were in this damage category, the majority being in the middle size classes. The major cause appeared to be heavy winter snows. Alongside, in the older 'parent' stand,planted in 1961 at around $1.5 \times 1.5 \mathrm{~m}$ spacings (4,444 stems/ha) and still standing at 4,200 stems/ha, the level of damage was significantly less, as the even spacing had allowed stems to grow to larger diameters and they were therefore more stable. As a result of the high number of trees with broken tops and bent stems in the naturally regenerated trial site, light levels at ground surface appeared to have increased significantly, which is likely to accelerate vegetation successions in the near future.

\section{Vegetation changes}

The main purpose of this trial was to monitor the invasion of high country grassland by contorta pine wildings, and the effect of conifer cover on the succession of other species over time. It is well known that vigorous introduced conifers can quickly suppress lower stature resident native species (Hunter \& Douglas 1984; Ledgard 1988), and in this trial the number of different species present between the early years (before major suppression occurred) and 2007, dropped from thirty-eight to just seven. Of the thirty-eight species 
TABLE 1: Species frequency (\% occurrence in all 250 frequency plots) of the most common species from 1980 to 2007 (* indicates native species).

\begin{tabular}{|c|c|c|c|c|c|}
\hline Species & 1980 & 1981 & 1984 & 1985 & 2007 \\
\hline \multicolumn{6}{|l|}{ Grasses } \\
\hline Agropyron scabrum* & 0 & 0.4 & 1.6 & 0.4 & 0 \\
\hline Agrostis capillaris & 15.6 & 1.6 & 25.6 & 32.4 & 0 \\
\hline Anthoxanthum odoratum & 38.4 & 38.4 & 23.2 & 5.2 & 0 \\
\hline Carex sp.* & 0 & 0.4 & 0 & 0.4 & 0 \\
\hline Festuca matthewsii* & 0 & 0 & 3.6 & 0.8 & 0 \\
\hline Festuca novae-zelandiae* & 7.6 & 6.4 & 0 & 1.2 & 0 \\
\hline Holcus lanatus & 0 & 0.4 & 0 & 0 & 0.4 \\
\hline Luzula rufa* & 0 & 0.4 & 0.8 & 0 & 0 \\
\hline Luzula sp.* & 2.8 & 1.6 & 0 & 0 & 0 \\
\hline Poa caespitosa* & 0.8 & 1.2 & 0 & 0 & 0 \\
\hline Poa colensoi* & 10 & 11.2 & 10.4 & 11.6 & 0 \\
\hline Poa pratense & 0 & 0 & 0.4 & 1.2 & 0 \\
\hline Rytidosperma semiannularis* & 0 & 0 & 0 & 0.4 & 0 \\
\hline Rytidosperma setifolia* & 0 & 2 & 0 & 0 & 0 \\
\hline Rytidosperma unarede* & 0.8 & 0 & 0.4 & 0 & 0 \\
\hline \multicolumn{6}{|l|}{ Herbs } \\
\hline Acaena sp.* & 4.8 & 5.6 & 4.4 & 3.2 & 0 \\
\hline Anisotome aromatica* & 7.2 & 8.8 & 6.4 & 6 & 0 \\
\hline Anisotome filiforme* & 2 & 6 & 0.4 & 0 & 0 \\
\hline Celmisia gracilenta* & 0 & 0.8 & 0.4 & 0 & 0 \\
\hline Celmisia spectabilis* & 0.8 & 0.4 & 0.4 & 0.4 & 0 \\
\hline Crepis capillaris & 0.4 & 0.4 & 0.4 & 0.8 & 0 \\
\hline Epilobium sp.* & 1.6 & 2 & 3.2 & 0.4 & 0 \\
\hline Helichrysum bellidioides* & 0.4 & 1.2 & 0.8 & 0 & 0 \\
\hline Hieracium lepidulum & 38 & 44 & 40.8 & 44.4 & 14 \\
\hline Hieracium praealtum & 4.4 & 4 & 4 & 0 & 2.8 \\
\hline Hypochoeris radicata & 1.2 & 0.8 & 0.4 & 0 & 0 \\
\hline Mycelis muralis & 0 & 0 & 0 & 2.8 & 0 \\
\hline Nertera sp.* & 0 & 0.8 & 0 & 0 & 0 \\
\hline Ranunculus sp. & 0 & 2.8 & 0 & 0 & 0 \\
\hline Raoulia subulata* & 4.4 & 0.4 & 0 & 0 & 0 \\
\hline Senecio lagopus* & 1.6 & 2 & 2.4 & 0.8 & 0 \\
\hline Trifolium repens & 0 & 0 & 0.4 & 0 & 0 \\
\hline Viola cunninghamii ${ }^{*}$ & 9.6 & 15.6 & 6.4 & 1.6 & 0 \\
\hline Wahlenbergia albomarginata* & 6.8 & 13.2 & 6.4 & 3.6 & 0 \\
\hline \multicolumn{6}{|l|}{ Shrubs } \\
\hline Dracopyllum procumbens* & 1.2 & 0.8 & 1.2 & 0.8 & 0 \\
\hline Gaultheria depressa* & 12.8 & 14.4 & 9.6 & 7.2 & 0 \\
\hline Hebe sp.* & 0 & 0 & 0 & 0.4 & 0 \\
\hline Leucopogon fraseri* & 0 & 0.4 & 0.4 & 0 & 0 \\
\hline Oreomyrrhis ramosa* & 0 & 0.4 & 1.6 & 0 & 0 \\
\hline Ozothamnus sp.* & 0.8 & 0.4 & 0 & 0 & 0 \\
\hline Pentachondra pumila* & 0 & 0.4 & 0 & 0 & 0 \\
\hline Pimelia prostrata* & 0.4 & 0.8 & 1.6 & 1.2 & 0 \\
\hline \multicolumn{6}{|l|}{ Trees $T$} \\
\hline Pinus contorta & 3.2 & 2 & 4 & 2.4 & 0 \\
\hline Pseudotsuga menziesii & 0 & 0 & 0 & 0 & 1.2 \\
\hline Sorbus aucuparia & 0 & 0 & 0 & 0 & 0.8 \\
\hline \multicolumn{6}{|l|}{ Ferns, mosses, lichens } \\
\hline Blechnum penna-marina* & 28.4 & 40.8 & 46.4 & 50.4 & 0 \\
\hline Lichen sp. & 1.2 & 0 & 0 & 0 & 0.8 \\
\hline Moss & 10.8 & 9.6 & 2 & 3.2 & 5.2 \\
\hline Peltigera sp. (lichen) & 0 & 0 & 0 & 0 & 0.4 \\
\hline
\end{tabular}


present initially, twenty-six (68\%) were indigenous. Amongst the top ten most frequently occurring species prior to 1985 were seven native species, but only one of these, a fern (B. penna-marina), occurred consistently in the top three. The most frequent introduced species were the hawkweed, H. lepidulum, and two grasses, sweet vernal and browntop. By 2007, no native species could be found in the trial area, and from all the 1985 top ten species, just two remained $-H$. lepidulum and $H$. praealtum - the former with a much reduced frequency. Hieracium lepidulum can be the most persistent invasive species under beech forests (Wiser et al. 1998). It was present throughout the 23 years of that author's study, and its occurrence in plots increased over that time. Therefore, it may have been continuously present in the Craigieburn study plot between 1985 and 2007. Two new species in 2007 were the introduced trees, Douglas-fir and rowan, both of which are present locally as mature trees. Despite an abundance of local seed, no young contorta pine seedlings were located, most likely because this species is shade-intolerant, requiring at least $40 \%$ of full sunlight to grow sufficiently vigorously to form a climax canopy (Lotan \& Perry 1983).

Within its North American home range, contorta pine stands are often colonised by more shade tolerant species as the canopy opens up and light levels increase (Lotan \& Perry 1983). This should also be the case in New Zealand, as long as there is a seed source present. There are a number of native species that can establish and grow well under introduced pine canopies, in light levels that are not high enough for pine seedlings to flourish (Allen et al. 1995). However, such colonisation may take some decades. McQueen (1993) reported that 40-50 year old contorta pine on the south side of Mt Ruapehu were dense and dark beneath, with no growth under them, indigenous or naturalised. However, during an earlier visit to the same area in 1988, one of the present authors (N.J. Ledgard) noted a range of native species (including red and mountain beech saplings up to $3 \mathrm{~m}$ high) growing well under planted 60 -year-old contorta pine stands. In addition, dense 30-40 year naturally regenerated wilding stands were starting to open up, under which a native understory was observed to be developing. There are a number of good examples of native understories growing under mature planted radiata pine stands - recorded by Henry (1954), McQueen (1961,1993), Ogden et al. (1997), Allen et al. (1995) and Brockerhoff et al. (2003).

In the present study area at Craigieburn, 30 years after the first contorta pine seedlings established in grasslands adjacent to 14-16 year old planted stands, virtually all the initial resident ground vegetation has been suppressed and disappeared. However, there are signs that the canopy is now opening up sufficiently to offer opportunities for more shadetolerant species to establish from seed. Apart from the two hawkweeds (H. lepidulum and $H$. praealtum), the former of which is known to persist in poor light (Wiser et al. 1998), two introduced woody species, Douglas-fir and rowan, were also recorded as small seedlings ( $<5 \mathrm{~cm}$ tall). Unless the canopy opens up further, and light levels increase considerably, it is doubtful if the Douglas-fir will persist, as the species requires $30-45 \%$ of full sunlight to grow vigorously (O'Hara 2002). There are many instances in New Zealand where young seedlings under intact canopies have not persisted to compete at canopy level (Ledgard 2002). Parent trees of both the Douglas-fir and rowan are present locally, and the seed is readily spread some distance by wind and birds respectively. Also present nearby is the native mountain beech, the seed of which is spread by wind, but it is not blown far (Wardle 1984), which may explain its absence. Other native species associated with the Craigieburn beech forest understory, such as broadleaf (Griselinea littoralis) and small-leaved Coprosma spp., are sparsely represented locally and a lack of readily available seed may hinder their wider spread.

Since the study site lies in an area administered by the Department of Conservation, the most desirable successional outcome would be the establishment of indigenous species, which would eventually lead to a climax native vegetation. At Craigieburn, this would be mountain beech forest. Mountain beech seedlings have been successfully established under pine canopies in the Craigieburn area (Ledgard \& Baker 1988), and some natural regeneration is already present under a contorta pine stand planted closer to a mountain beech margin. However, for such a succession to occur within the study area, beech seed may need to be artificially introduced, as it does not appear to be arriving naturally. 


\section{ACKNOWLEDGEMENTS}

Major thanks are owed to Pam McDonald, the Forest Research Institute technician who oversaw the trial and collated the records between 1980 and 1985. It is largely due to her diligence that the trial was able to be successfully remeasured in 2007. She was helped in the area of plant identification by scientist, Graham Evans. Marie Charru, an exchange student from Agroparistech, Paris, France, assisted with the 2007 measurements and data entry.

\section{REFERENCES}

Allen RB, Rose AB, Evans, GR 1983. Grassland survey manual: A permanent plot method. Forest Research Institute. Forest Research Institute Bulletin No $43.71 \mathrm{pp}$.

Allen R, Platt K, Wiser S 1995. Biodiversity in New Zealand plantations. New Zealand Forestry 39(4): 26-29.

Brockerhoff EG, Ecroyd EC, Leckie AC, Kimberley MO 2003. Diversity and succession of adventive and indigenous vascular understorey plants in Pinus radiata plantation forests in New Zealand. Journal of Forest Ecology and Management 185: 307-326.

Henry JE 1954. The development of native vegetation on pumice country, and its relationship with exotic pine forest. New Zealand Journal of Forestry 7: 79-82.

Hewitt AE 1992. New Zealand Soil Classification. Department of Scientific and Industrial Research Land Resources Scientific Report No 19. 133 pp.

Hunter GG, Douglas MH 1984. Spread of exotic conifers on South Island rangelands. New Zealand Journal of Forestry Science 29(1): 78-96.

Ledgard NJ 1988. The spread of introduced trees in New Zealand's rangelands - South Island high country experience. Tussock Grasslands and Mountain Lands Institute Review 44: 1-7.

Ledgard NJ 2001. The spread of Lodgepole pine (Pinus contorta, Dougl.) in New Zealand. Journal of Forest Ecology and Management 141: 43-57.

Ledgard NJ 2002. The spread of Douglas-fir into native forests. New Zealand Journal of Forestry 47(2): 36-38.

Ledgard NJ 2004. Wilding conifers - New Zealand history and research background. In: Hill, RL, Zydenbos SM, Bezar CM ed. Managing wilding conifers in New Zealand - present and future. New Zealand Plant Protection Society, Christchurch, New Zealand [ISBN 0-478-10842-7]. Pp. 1-25.

Ledgard NJ, Baker GC 1988. Mountainland forestry - 30 year's research in the Craigieburn Range, New Zealand. New Zealand Forest Research Institute Bulletin No $146.64 \mathrm{pp}$.

Lotan JE, Perry DA 1983. Ecology and regeneration of Lodgepole pine. United States Department of Agriculture Handbook No 606. 51 pp.

McQueen DR 1961. Indigenous-induced vegetation and Pinus radiata on volcanic ash soils. New Zealand Ecological Society Proceedings 8. Pp. 1-14.

McQueen DR 1993. A review of the interaction between naturalised woody plants and indigenous vegetation in New Zealand. Tuatara 32: 32-49.

New Zealand Department of Scientific and Industrial Research 1968. General survey of the soils of the South Island, New Zealand. Soil Bureau Bulletin 27. 404 pp.

Ogden J, Braggins J, Stretton K, Anderson S. 1997. Plant species richness under Pinus radiata stands on the central N. Island volcanic plateau, New Zealand. New Zealand Journal of Ecology 21: 17-19.

O'Hara KL 2002. The historical development of uneven-aged silviculture in North America. Forestry 75(4): 339-346.

Wardle J 1984. The New Zealand beeches - ecology, utilisation and management. New Zealand Forest Service, Caxton Press, Christchurch [ISBN 0-477-05753-5]. 447 pp.

Wiser SK, Allen RB, Clinton PW, Platt KH 1998. Community structure and forest invasion by an exotic herb over 23 years. Ecology 79(6): 2071-2081. 